\title{
COMPARATIVE STATISTICAL ANALYSIS OF GENDER EQUALITY ON THE LABOUR MARKETS OF ROMANIA AND EU28 ${ }^{1}$
}

Daniela PAŞNICU, Prof. PhD

Spiru Haret University

National Scientific Research Institute for Labour and Social Protection

E-mail: danielapasnicu@yahoo.com

\begin{abstract}
To achieve the employment target set in the Europe 2020 Strategy is necessary that women's potential and talent to be used optimally. Increasing employment for both men and women is the main way to achieve autonomy, financial independence and poverty reduction.

This paper presents a comparative statistical analysis of gender equality on the labour markets of Romania and EU28 based on official statistics records and specific key labour market indicators. The aim was to highlight the gender gap on activity rates, employment rates by age, work time and unemployment rate, including long-term unemployment. The analyses undertaken shows that in the last ten years activity and employment rates of women in Romania had a slightly decreasing trend, while at the EU28 level had an upward trend, which led to the widening gap than the average EU28. The gender gap for the same indicators rose in the period under review, in the case of Romania, while at the EU28 level decreased.
\end{abstract}

Keywords: gender gap, gender equality, employment rate, unemployment rate, activity rate

JELL Classification: $\mathrm{J}_{16}, \mathrm{~J}_{21}$

\section{Introduction}

European Union committed by the Treaty of Amsterdam (1999) to promote equality between women and men and to integrate it in the community activities at all levels. In the European Strategy for equality between women and men, for the period 2010-2015 are described concrete actions for each priority area, in a twintrack approach, combining mainstreaming equal opportunities with specific measures. The five priority areas of the strategy are: equal economic independence; equal pay for equal work and work of equal value; equality in decision-making; dignity, integrity and termination the gender-based violence; equality between women and men in external actions. In addition to the five priority areas in the Strategy are presented a series of cross-cutting issues, including the need to develop an annual report on gender equality. The equality of opportunity and

\footnotetext{
${ }^{1}$ This paper is supported by Project ProFemin, POSDRU/144/6.3/S/126567.
} 
treatment between men and women means taking into account the capacities, needs and aspirations of different males, respectively, female and their equal treatment.

The presence of more women in the labour market may counterbalance the effects of the diminishing population of working age on the sustainability of social protection systems, enhancing in the same time human capital base and creating competitiveness. European employment objective of $75 \%$ of people aged between 20 and 64, set in the Europe 2020 strategy will can be achieved only if more women participate in the labour market. In order to increase their employment in the National Strategy for Equality between Women and Men for the period 20142017 it is outlined the need that policies to remain focused on the use of untapped potential, or under-exploited, of the women who are outside of the labour market or who do not exploit their full potential of the labour market. In Romania, equal opportunities and equal treatment between women and men is a fundamental principle of human rights, implemented at legislative and public policies level. This principle is established in Law no. 202/2002 on equal opportunities and equal treatment between women and men, republished in 2013, which governing measures for promoting equal opportunities and equal treatment between women and men in all spheres of public life from Romania.

\section{Recent studies on the progress of gender equality}

The summary report on the impact of the economic crisis on gender equality (Francesca Bettio, Marcella Corsi, et other, 2012) identified four main conclusions, namely: 1) reduction in the recession period of the gender gap on employment, unemployment, wages and poverty, but without reflecting progress on gender equality as long as reducing the gender gap is based on lower employment rates, higher unemployment rates and lower earnings for both men and women; 2) during the economic crisis the behaviour of women on the labour market was similar to that of men; 3) reduction in the recession of the gender gap on poverty as a result of social transfers; 4) to most countries gender mainstreaming has not been implemented in the economic policies during the crisis period. In response to the economic crisis it is estimated that the impact of gender was taken into account at all stages of policy in about a tenth of policy initiatives implemented in the National Reform Programs.

In Report on progress on Equality between Women and Men in 2013 (European Commission, 2014) stresses that progress has been made in most areas, "but uneven year achieved at peace." At this rate of change will take almost 30 years to achieve the target that $75 \%$ of women be employed in the labour market, over 70 years to make equal pay a reality, over 20 years to achieve parity in national Parliaments, over 20 years to reach equilibrium in the steering Committees of the largest companies in Europe and almost 40 years to achieve gender equality in solving housework. 
Evolution of activity rate, employment rate and unemployment rate by sex

\section{Comparative analysis at Romania and EU28 level}

Analysing the data in Table 1, we see that activity rates for women are much lower in Romania than those recorded in the EU28, in 2013 they reached values of $66 \%$ in the EU28, and $56.5 \%$ in Romania. The gap between the activity rates of women registered in the EU28 and Romania increased in the period under review from 2.8 p.p. in 2002 to 9.5 p.p. in 2013. The gap between the activity rates of men from Romania and EU28 registered lower values compared to those of women, reaching a maximum of 7.9 p.p. in 2005 and a minimum of 5.3 p.p. in 2013. Evolution of the activity rate for women in Romania had a decreasing trend, reaching a decrease of 1.1 p.p. in the period under review. In the EU28 is recorded for the same period an increase in the activity rate for women by $6.7 \mathrm{pp}$. Regarding gender differences recorded in Romania and EU28, they have increased in Romania with 2.8 p.p., while in the EU28 they fell with 4,4p.p.

Female activity rate decreased between 2002 and 2013 in Romania, while in the EU28 increased by 5.6 p.p. For the other intervals analysed, namely 2008 to 2013 and from 2010 to 2013 activity rates increases in Romania for female were lower than those recorded in the EU, while the values recorded for increases of the male activity rate are superior in Romania's case.

Tab1e 1. Evolution of activity rate for working age population (15-64 years)

by gender, during 2002-2013 (\%)

\begin{tabular}{|c|c|c|c|c|c|c|c|c|c|c|c|c|}
\hline \multirow[b]{3}{*}{ Years } & \multicolumn{12}{|c|}{ Activity rate } \\
\hline & \multicolumn{4}{|c|}{ Romania } & \multicolumn{4}{|c|}{ EU28 } & \multicolumn{4}{|c|}{ Gap to EU28 } \\
\hline & Total & Women & Man & $\begin{array}{c}\text { Gender } \\
\text { gap }\end{array}$ & Total & Women & Man & $\begin{array}{c}\text { Gender } \\
\text { gap }\end{array}$ & Total & Women & Man & $\begin{array}{c}\text { Gender } \\
\text { gap }\end{array}$ \\
\hline 2002 & 64,2 & 57,6 & 71,0 & 13,4 & 68,6 & 60,4 & 76,8 & 16,4 & 4,4 & 2,8 & 5,8 & 3,0 \\
\hline 2003 & 63,4 & 56,7 & 70,2 & 13,5 & 68,9 & 61,0 & 76,8 & 15,8 & 5,5 & 4,3 & 6,6 & 2,3 \\
\hline 2004 & 63,9 & 57,2 & 70,8 & 13,6 & 69,2 & 61,5 & 76,9 & 15,4 & 5,3 & 4,3 & 6,1 & 1,8 \\
\hline 2005 & 62,3 & 55,3 & 69,4 & 14,1 & 69,7 & 62,2 & 77,3 & 15,1 & 7,4 & 6,9 & 7,9 & 1,0 \\
\hline 2006 & 63,6 & 56,6 & 70,7 & 14,1 & 70,2 & 62,9 & 77,5 & 14,6 & 6,6 & 6,3 & 6,8 & 0,5 \\
\hline 2007 & 63,0 & 56,0 & 70,1 & 14,1 & 70,4 & 63,2 & 77,6 & 14,4 & 7,4 & 7,2 & 7,5 & 0,3 \\
\hline 2008 & 62,9 & 55,2 & 70,6 & 15,4 & 70,7 & 63,7 & 77,8 & 14,1 & 7,8 & 8,5 & 7,2 & $-1,3$ \\
\hline 2009 & 63,1 & 55,4 & 70,9 & 15,5 & 70,9 & 64,1 & 77,7 & 13,6 & 7,8 & 8,7 & 6,8 & $-1,9$ \\
\hline 2010 & 63,6 & 55,8 & 71,5 & 15,7 & 70,9 & 64,4 & 77,5 & 13,1 & 7,3 & 8,6 & 6,0 & $-2,6$ \\
\hline 2011 & 63,3 & 56,0 & 70,7 & 14,7 & 71,1 & 64,8 & 77,5 & 12,7 & 7,8 & 8,8 & 6,8 & $-2,0$ \\
\hline 2012 & 64,2 & 56,4 & 72,1 & 15,7 & 71,7 & 65,5 & 77,9 & 12,4 & 7,5 & 9,1 & 5,8 & $-3,3$ \\
\hline 2013 & 64,6 & 56,5 & \begin{tabular}{l|l|}
72,7 \\
\end{tabular} & 16,2 & 72,0 & 66,0 & 78,0 & 12,0 & 7,4 & 9,5 & 5,3 & $-4,2$ \\
\hline
\end{tabular}

Source: author processing based on Eurostat data, LFS, [1fsa_argan]

Analysing the data in table 2 we see that employment rates in Romania both in total and by gender, are lower than those recorded in the EU28. The gap of activity rate for women recorded in EU28 and Romania, has increased significantly in the period under review, reaching in 2013 at 6.2 p.p., being higher than for men (2.6 p.p.). Gender gaps in employment rate have increased in Romania, while it 
decreased in the EU. In Romania, the gender gaps reaching in 2013 at value of 14.2 p.p., with 3.6 p.p. higher than in the EU28. The decrease in the employment rate of women more than men in Romania can be observed especially after 2008, showing that women were more affected by the economic crisis compared with men.

Female employment rate in Romania recorded a decrease of 0.2 p.p. in the period 2013/2002, while in the EU28 level is a significant increase, with 4.4 p.p. In the period 2013/2008 there were not increases for the EU and for Romania the increases was insignificant, 0.1 p.p., a sign that the economic crisis has not yet been fully improved. In the period 2010-2013 is a slight increase of this in Romania and in EU 28. Male employment rate has been growing in Romania for all periods analysed, while in the EU it registered decreases, the most significant being the period 2013/2008. It can be concluded that economic crisis affected at the EU28 level mainly the male population, unlike the situation in Romania.

Table 2. Evolution of employment rate for working age population (15-64 years) by gender, during 2002-2013 (\%)

\begin{tabular}{|c|c|c|c|c|c|c|c|c|c|c|c|c|}
\hline \multirow[b]{3}{*}{ Years } & \multicolumn{12}{|c|}{ Employment Rate } \\
\hline & \multicolumn{4}{|c|}{ Romania } & \multicolumn{4}{|c|}{ EU28 } & \multicolumn{4}{|c|}{ Gap to UE28 } \\
\hline & Total & Women & Man & $\begin{array}{c}\text { Gender } \\
\text { gap }\end{array}$ & Total & Women & Man & $\begin{array}{c}\text { Gender } \\
\text { gap }\end{array}$ & Total & Women & Man & $\begin{array}{c}\text { Gender } \\
\text { gap }\end{array}$ \\
\hline 2002 & 58,6 & 52,8 & 64,5 & 11,7 & 62,3 & 54,4 & 70,3 & 15,9 & 3,7 & 1,6 & 5,8 & 4,2 \\
\hline 2003 & 58,7 & 52,8 & 64,7 & 11,9 & 62,6 & 55,0 & 70,3 & 15,3 & 3,9 & 2,2 & 5,6 & 3,4 \\
\hline 2004 & 58,7 & 53,5 & 64,1 & 10,6 & 62,7 & 55,3 & 70,2 & 14,9 & 4,0 & 1,8 & 6,1 & 4,3 \\
\hline 2005 & 57,6 & 51,5 & 63,7 & 12,2 & 63,4 & 56,0 & 70,8 & 14,8 & 5,8 & 4,5 & 7,1 & 2,6 \\
\hline 2006 & 58,8 & 53,0 & 64,6 & 11,6 & 64,3 & 57,2 & 71,6 & 14,4 & 5,5 & 4,2 & 7,0 & 2,8 \\
\hline 2007 & 58,8 & 52,8 & 64,8 & 12,0 & 65,3 & 58,1 & 72,4 & 14,3 & 6,5 & 5,3 & 7,6 & 2,3 \\
\hline 2008 & 59,0 & 52,5 & 65,7 & 13,2 & \begin{tabular}{|l|}
65,7 \\
\end{tabular} & 58,8 & 72,7 & 13,9 & 6,7 & 6,3 & 7,0 & 0,7 \\
\hline 2009 & 58,6 & 52,0 & 65,2 & 13,2 & 64,5 & 58,4 & 70,6 & 12,2 & 5,9 & 6,4 & 5,4 & $-1,0$ \\
\hline 2010 & 58,8 & 52,0 & 65,7 & 13,7 & 64,0 & 58,1 & 70,0 & 11,9 & 5,2 & 6,1 & 4,3 & $-1,8$ \\
\hline 2011 & 58,5 & 52,0 & 65,0 & 13,0 & 64,2 & 58,4 & 70,0 & 11,6 & 5,7 & 6,4 & 5,0 & $-1,4$ \\
\hline 2012 & 59,5 & 52,6 & 66,5 & 13,9 & 64,1 & 58,6 & 69,6 & 11,0 & 4,6 & 6,0 & 3,1 & $-2,9$ \\
\hline 2013 & 59,7 & 52,6 & 66,8 & 14,2 & 64,1 & 58,8 & 69,4 & 10,6 & 4,4 & 6,2 & 2,6 & $-3,6$ \\
\hline
\end{tabular}

Source: author processing based on data Eurostat, LFS, [lfsa_ergan]

Analysing the data in Table 3 it can be seen that the unemployment rate is higher in the EU28, compared to that in Romania. The situation in Romania is slightly unusual, given that the employment rate among women is below average EU28 with 9.5 p.p., and the unemployment rate is also lower with 6.2 p.p. This means that a share important of women are housewives, went to work abroad or not appearing as people looking for a job. The gender gap in unemployment rate in Romania is higher than in the EU28, illustrating the limited employment opportunities for men. Unemployment increased in the EU 28 in all analysed periods, both women and men. A significant increase was recorded in EU in the period 2013/2008, respectively for men 3.3 p.p. and 4.3 p.p. for women. In Romania there have been increases both women and men only for the period 2013/2008, most significant for women and much lower than those recorded in the 
EU28. It can be seen that in Romania women were more affected by unemployment than men, while in the EU, men were more affected than women.

Table 3. Evolution of unemployment rate for working age population (15-64 years) by gender, during 2002-2013 (\%)

\begin{tabular}{|c|c|c|c|c|c|c|c|c|c|c|c|c|}
\hline \multirow[b]{3}{*}{ Years } & \multicolumn{12}{|c|}{ Unemployment rate } \\
\hline & \multicolumn{4}{|c|}{ Romania } & \multicolumn{4}{|c|}{ EU28 } & \multicolumn{4}{|c|}{ Gap to UE28 } \\
\hline & Total & Women & Man & $\begin{array}{c}\text { Gender } \\
\text { gap }\end{array}$ & Total & Women & Man & $\begin{array}{c}\text { Gender } \\
\text { gap }\end{array}$ & Total & Women & Man & $\begin{array}{c}\text { Gender } \\
\text { gap }\end{array}$ \\
\hline 2002 & 8,8 & 8,3 & 9,1 & 0,8 & 9,1 & 10,0 & 8,4 & $-1,6$ & 0,3 & 1,7 & $-0,7$ & $-2,4$ \\
\hline 2003 & 7,4 & 6,8 & 7,8 & 1,0 & 9,2 & 9,9 & 8,6 & $-1,3$ & 1,8 & 3,1 & 0,8 & $-2,3$ \\
\hline 2004 & 8,1 & 6,5 & 9,4 & 2,9 & 9,3 & 10,0 & 8,8 & $-1,2$ & 1,2 & 3,5 & $-0,6$ & $-4,1$ \\
\hline 2005 & 7,5 & 6,8 & 8,1 & 1,3 & 9,1 & 9,8 & 8,4 & $-1,4$ & 1,6 & 3,0 & 0,3 & $-2,7$ \\
\hline 2006 & 7,6 & 6,4 & 8,5 & 2,1 & 8,3 & 9,1 & 7,7 & $-1,4$ & 0,7 & 2,7 & $-0,8$ & $-3,5$ \\
\hline 2007 & 6,8 & 5,7 & 7,6 & 1,9 & 7,2 & 8,0 & 6,7 & $-1,3$ & 0,4 & 2,3 & $-0,9$ & $-3,2$ \\
\hline 2008 & 6,1 & 5,0 & 7,0 & 2,0 & 7,1 & 7,6 & 6,7 & $-0,9$ & 1,0 & 2,6 & $-0,3$ & $-2,9$ \\
\hline 2009 & 7,2 & 6,2 & 8,0 & 1,8 & 9,0 & 9,0 & 9,1 & 0,1 & 1,8 & 2,8 & 1,1 & $-1,7$ \\
\hline 2010 & 7,6 & 6,9 & 8,2 & 1,3 & 9,7 & 9,7 & 9,8 & 0,1 & 2,1 & 2,8 & 1,6 & $-1,2$ \\
\hline 2011 & 7,7 & 7,1 & 8,2 & 1,1 & 9,8 & 9,8 & 9,7 & $-0,1$ & 2,1 & 2,7 & 1,5 & $-1,2$ \\
\hline 2012 & 7,3 & 6,7 & 7,8 & 1,1 & 10,6 & 10,6 & 10,6 & 0,0 & 3,3 & 3,9 & 2,8 & $-1,1$ \\
\hline 2013 & 7,6 & 6,9 & 8,1 & 1,2 & 11,0 & 10,9 & 11,0 & 0,1 & 3,4 & 4,0 & 2,9 & $-1,1$ \\
\hline
\end{tabular}

Source: author processing based on data Eurostat, LFS, [1fsa_urgan]

Gender gap curve of unemployment rate for Romania has a downward trend after 2008, explained by the sharp increase in the unemployment rate for women than men in this period. This can be explained by greater employment of women in jobs with a higher degree of volatility, due to the outbreak of the economic crisis which led to a deterioration of employment of women compared to men. We can see that despite the measures taken in the period under review to reduce the gender gap on employment, the employment gender gap is maximum values, marking a deterioration of labour market conditions for women.

\section{Comparative analysis of the evolution of the employment rate by sex and} age in the RO and EU28

The values recorded for men and women employment rate in the three age ranges considered are superior at EU28 level, graph 1 and graph 2.

By age groups, the employment rate for men and women recorded the highest values for the age group 25-54 and lowest values for the age group 15-24 years. Man employment rate for the age group 25-54 years has approximately constant trend in the period considered, the values hovering between $80 \%$ and $81.7 \%$, in 2013 reaching at $81.6 \%$, with 0.9 p.p. under the value registered at EU level.

Men employment rate for the age group 55-64 records values in the range $42.7 \%$ and $53 \%$ for Romania and somewhat higher for EU, ranging between $48 \%$ and $57.5 \%$. The trend is slightly upward curves for both Romania and the EU, with a maximum in 2008, in the case of Romania and in 2013, in the case of EU. The fact that employment declined in Romania in the period 2008-2013 with 1.5 p.p., compared with EU level, where it increased with 2.6 p.p. indicates that the 
population of this category was most affected in Romania by economic crisis compared to the EU level. The same trends can be observed in the case of women, where the increase in EU 28 was 6.6 p.p. and decrease in Romania was 1.7 p.p.

The values of men employment rate for the 15-24 age group are in the range $27.3 \%$ and $32.3 \%$ for Romania and between $34.2 \%$ and $40.3 \%$ for the EU. Both curves showed a downward trend in both periods 2002-2013 and 2008-2013 and, in the last case the decrease being 6.1 p.p. in the EU and 1.7 p.p. in Romania. The women employment rate has in 2008-2013 period a constant evolution for Romania and a decrease with 4 p.p. for EU 28.

Graph 1: Employment rate by age group, men (\%)

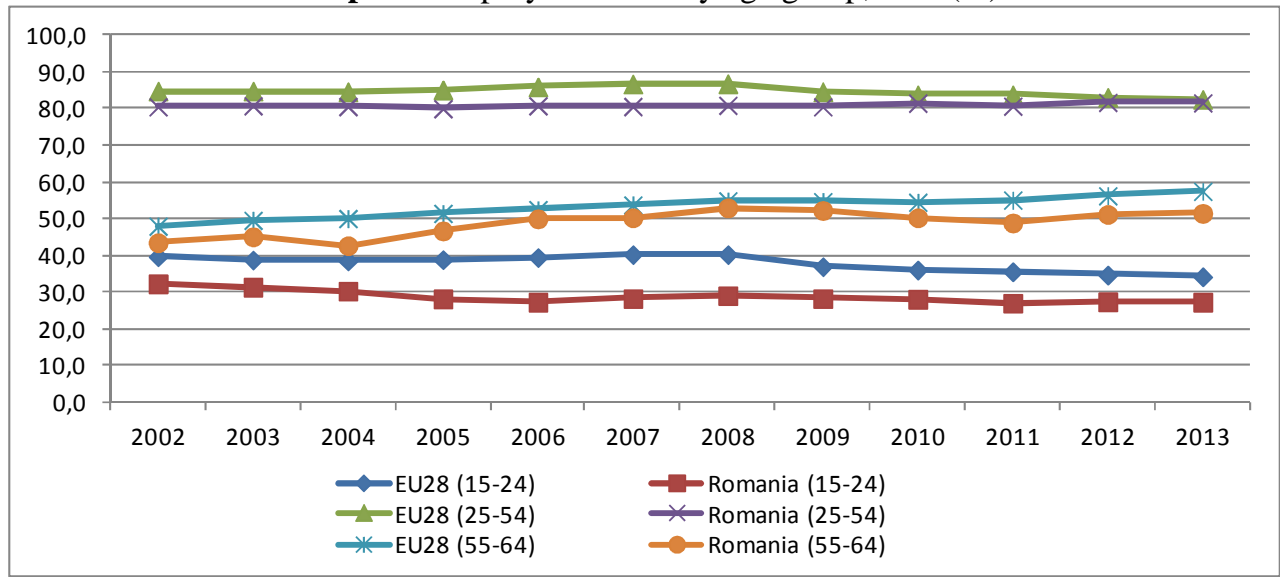

Source: author processing based on data Eurostat, LFS

Graph 2: Employment rate by age group, women (\%)

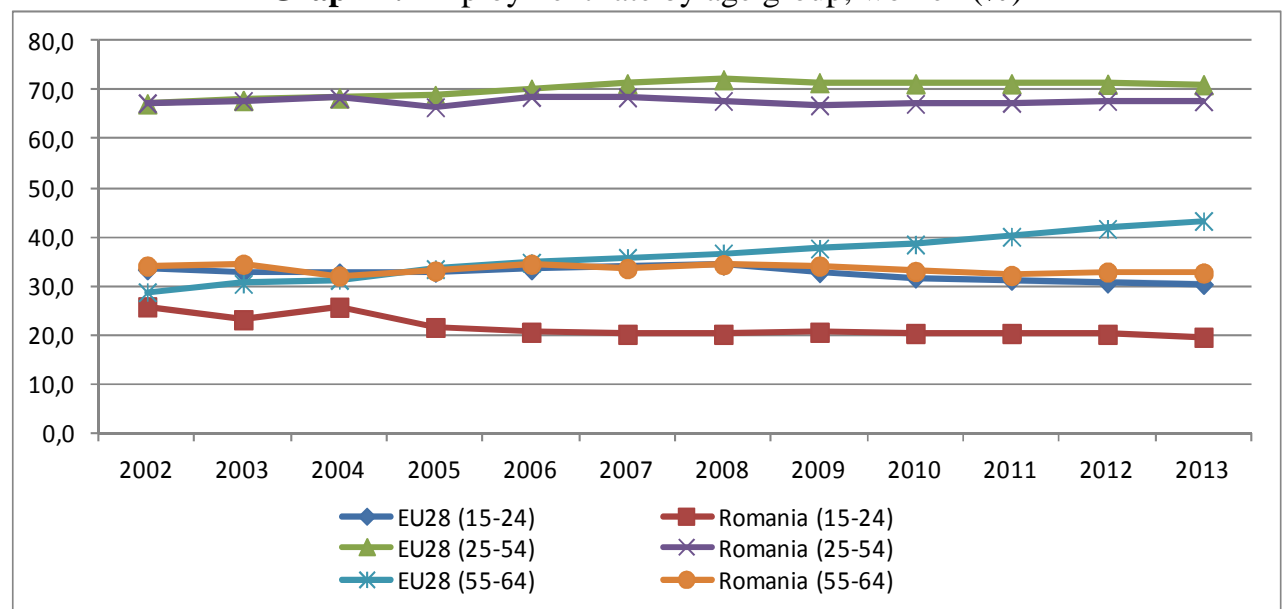

Source: author processing based on data Eurostat, LFS

60 


\section{The share of long-term unemployed to total unemployed, by gender}

In graph 3 we can see that in 2013 the top three countries with high share of long-term unemployed in total unemployed among both men and women were: Slovakia, Greece and Croatia. Countries with negative gender gap, i.e. with a higher share of long-term unemployment in total unemployment among women compared to men are: Denmark; Rep. Portugal, Romania, Greece, Spain, Lithuania and Poland. In the EU28, the share of long-term unemployed women in unemployed women was one per cent lower than that of men, while in Romania it was higher by 3 per cent compared with that of men.

Graph 3: The share of long-term unemployed to total unemployed, by gender, $2013(\%)$

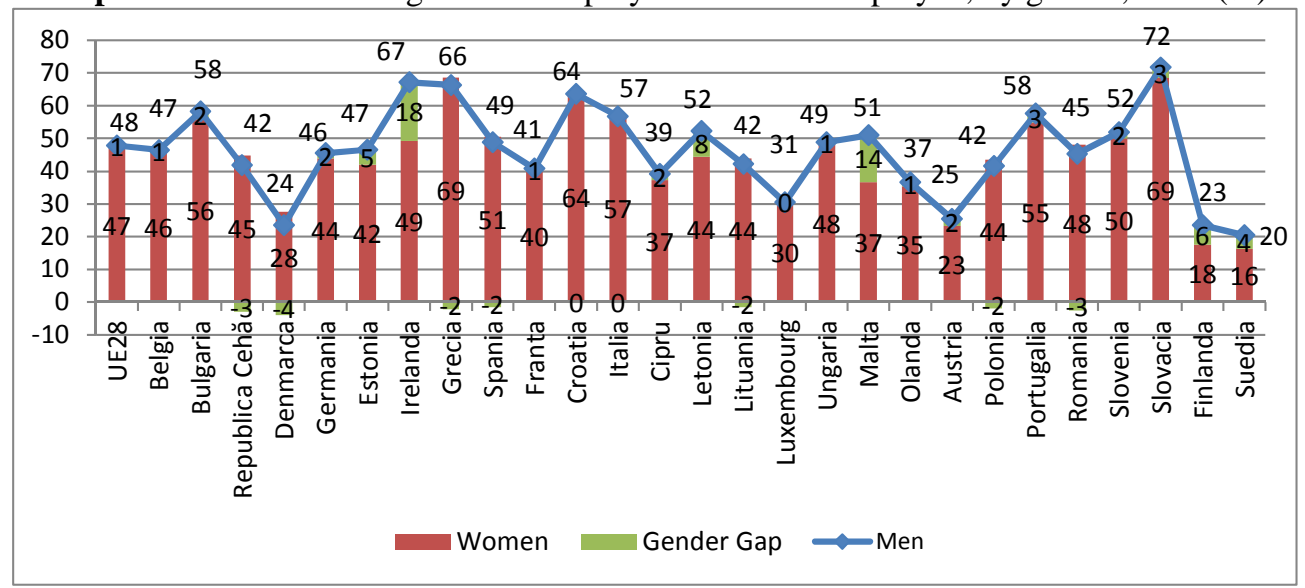

Source: author processing based on data Eurostat, LFS

Evolution of the share of part-time employment and involuntary part-time employment in total employment by gender

In graph 4, it can be seen that in EU28 share of women employed part time in total female employment is far superior to men; the gender gap has high values during the analysed period, varying in the range of at least $22.1 \%$ in 2002 and less than $23.7 \%$ in 2005 and 2007 . The share of women employed part-time in the EU28 is much higher than that recorded in Romania, the gap with an upward trend in the period under review, with a maximum of $22.8 \%$ recorded in 2013. This indicates greater flexibility of the labour market in the EU compared to that of Romania. In Romania, the share of women employed part time is slightly higher than the share of men employed part time, the gender gap being in the range from $0.1 \%$ in 2005 and $1.8 \%$ in 2002. The share of men employed part time in Romania is slightly higher than that recorded in the EU throughout the period considered, except in 2013. 
Graph 4: Evolution of the share of part-time employment on gender for Romania and EU28 (\%)

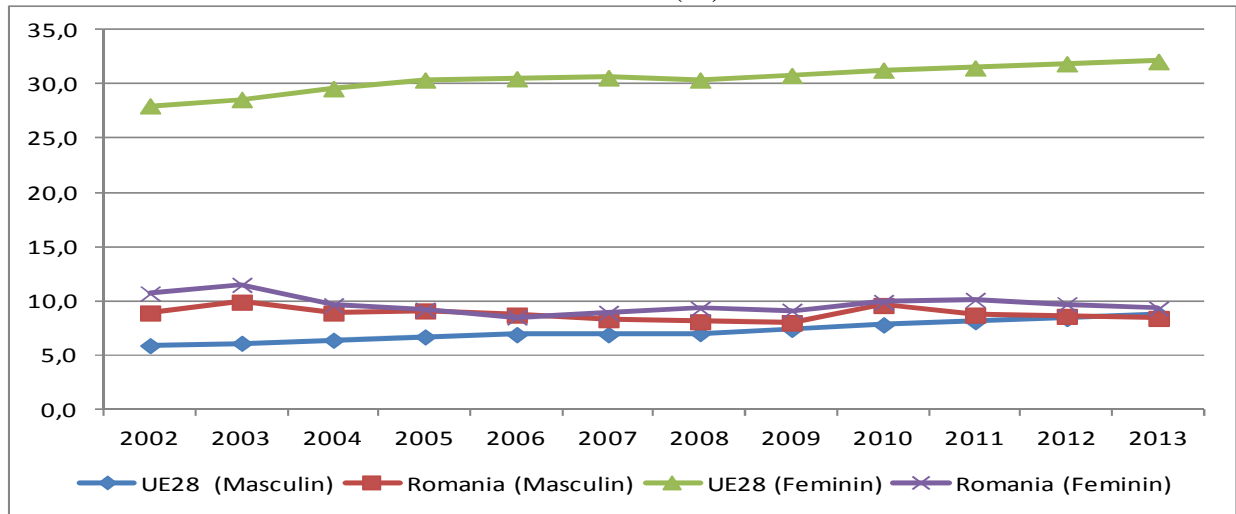

Source: Eurostat, LFS

The proportion of men working part-time involuntarily in Romania has the highest values, ranging between $60 \%$ and $70 \%$ (Graph 5). Also, the share of women working part-time involuntarily is superior to those recorded in the EU28, throughout the period under review. It can be seen that the share of women working involuntarily EU28 is higher than that of men, while in Romania the situation is the reverse.

Graph 5: Evolution of the share of part-time involuntarily employment on gender, Romania and EU28 (\%)

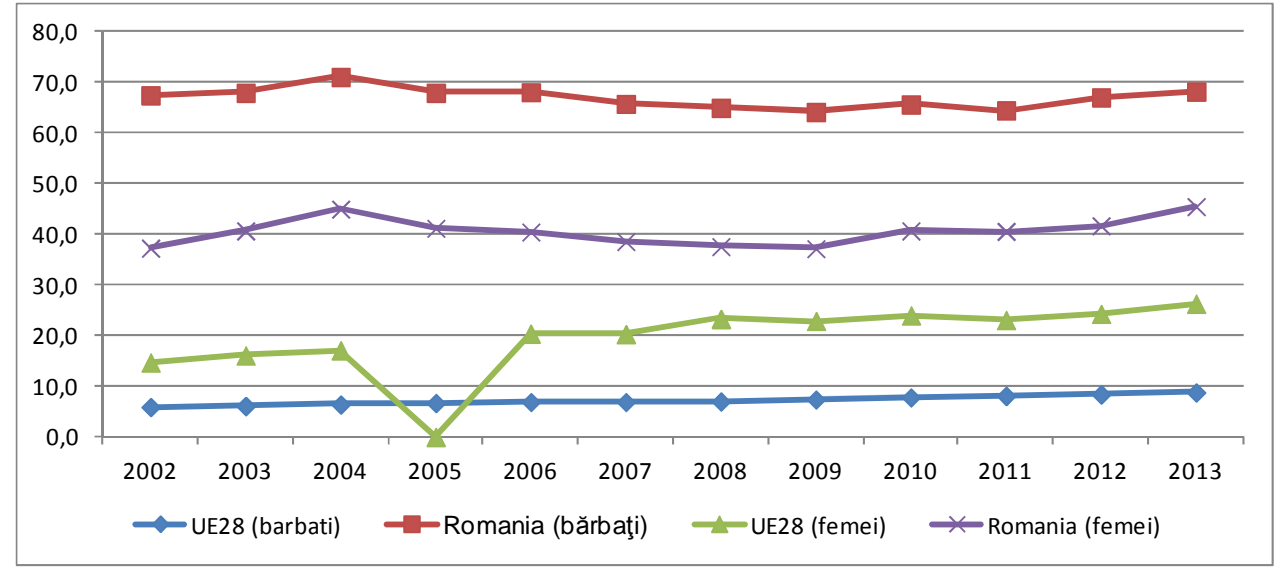

Source: Eurostat, LFS

Note: Data unavailable for part-time employment share of women in the EU in 2005

\section{Conclusions}


Activity and employment rates in Romania are lower than the EU28 average for both women and men. In the last ten years, especially after the economic crisis, it appears that the gap between the values recorded for these indicators in Romania toward the average EU28, increased for women, while for men fell. This is explained by the fact that activity and employment rates of women in Romania had a slightly decreasing trend, while in the EU28 had an upward trend, which led to the widening gap as against EU28 average. Also, in the period under review, the gender gap for the same indicators increased in the case of Romania, while for EU28 fell. Regarding the gender gap on the activity rate in 2013, Romania is among the countries with high, after Malta, Italy and Greece, and on the employment rate after Malta, Greece, Italy and the Czech Republic.

Unemployment rate in Romania is higher for men, and the values recorded for both men and women are inferior to those of the EU28 average. Curve gender gap in unemployment rate for Romania has a downward trend after 2008, explained by the sharp increase in unemployment among women compared to men, in the period under review.

Employment rate recorded higher values for all three age groups in the EU28 compared to Romania for both men and women. The lowest values were recorded for the age group 15-24 years. The age group most affected by the economic crisis in Romania compared to the EU28 was 55-64 years old, both for men and for women. Employment trend curves for age group 15-24 was decreasing both in the range 2002-2013 and between 2008-2013, in the latter case the decline was 1.7 p.p. for EU28 and 6.1 p.p. for Romania.

In Romania, the share of long-term unemployed women was above average EU.28, being higher than that of men with 3 p.p.

The share of part-time employment of women in the EU28 is much higher than that of Romania. Gender gaps in the share of part time employment in 2013 reached $23.3 \%$ in the EU28 value, much higher than in Romania and 0.9\%. This indicates a more flexible labour market in the EU28 compared to that of Romania.

\section{References}

Sănduleasa Andra-Bertha (2014), Romanians attitudes towards mobility for work from a gendered perspective, Annals of Spiru Haret University, vol. 5(14), issue 4: 29-36.

Paşnicu Daniela, Mladen Luise (2011), Analysis of gender gaps in profession, careers and pay, Annals of Spiru Haret University, vol. 2(11), issue 3: 61-72.

Bettio Francesca, Corsi Marcella et al. (2013), The impact of the economic crisis on the situation of women and men and on gender equality policies, European Union.

*** Legea nr. 202/2002 privind egalitatea de şanse şi de tratament între femei şi bărbaţ̧, republicată 2013.

*** Planul general de acțiuni pentru perioada 2014-2017 pentru implementarea Strategiei, aprobată prin hotărârea 1050 .

*** Strategia naţională în domeniul egalităţii de şanse între femei şi bărbaţi pentru perioada 2014-2017.

*** Strategia Uniunii Europene pentru egalitate între femei şi bărbaţi, 2010-2015.

*** The impact of the economic crisis on the situation of women and men and on gender equality policies, 2013. 
**** Report on progress on equality between women and men in 2013, Brussels, 2014.

http://ec.europa.eu/eurostat 